\title{
The Contemporary Revival of Confucianism
}

Anshen liming or the Religious Dimension of Confucianism

\section{Sébastien Billioud and Joël Thoraval}

\section{(2) OpenEdition}

\section{Journals}

Electronic version

URL: http://journals.openedition.org/chinaperspectives/4123

DOI: 10.4000/chinaperspectives. 4123

ISSN: 1996-4617

\section{Publisher}

Centre d'étude français sur la Chine contemporaine

\section{Printed version}

Date of publication: 1 July 2008

Number of pages: 88-106

ISSN: 2070-3449

\section{Electronic reference}

Sébastien Billioud and Joël Thoraval, «The Contemporary Revival of Confucianism », China Perspectives [Online], 2008/3 | 2008, Online since 01 July 2011, connection on 28 October 2019. URL http://journals.openedition.org/chinaperspectives/4123; DOI : 10.4000/chinaperspectives.4123

(C) All rights reserved 


\title{
Anshen liming or the Religious Dimension of Confucianism
}

\author{
SÉBASTIEN BILLIOUD AND IOËL THORAVAL
}

Since the beginning of the century, the resurgence in Mainland China of what is referred to as "Confucianism" has included a "religious" dimension. The term "religious" is here used to characterise a variety of explorations where the quest for "inner peace" also echoes a concern for individual or collective destiny (anshen liming). In order to understand these phenomena better, this article first examines an individual story that provides insight into what a Confucian religious experience may be today. This example is then placed within the context of shifting categories (religion, philosophy, science) once accepted as self-evident but now being questioned by elites and other groups in society. Finally, to give a sense of various explicit projects oriented towards achieving recognition of Confucianism as an official and institutionalised religion, the article analyses three such efforts seeking to institute Confucianism either as a "religion on par with other official religions," as the "state religion," or as "civil religion."

$\mathrm{T}$ here is no doubt that the signs of "Confucian revival" in China have been manifold since the beginning of this century; less clear, however, is the actual significance of contemporary aspirations toward reactivating Confucianism's religious dimension. Given the abolition of the imperial cult of Heaven, the transformation of the traditional academies into modern institutions of learning, the reduction of ancestor worship, and the refashioning of Temples of Culture (wenmiao) into tourist destinations, one can wonder to what extent Confucianism-inspired religiosity might be today more imaginary than real. Could it not be said that contemporary discourses rooted in Confucianism have less to do with the present than with the past or the future, both in terms of commemorating ancient rituals and of dreaming up utopian schemes for their possible restoration? In fact, the modern perspectives claiming such a prestigious past can only be properly understood within the context of a turbulent history that has seen the internal transformation of society and Western influences interact and alter the overall religious landscape. Nevertheless, despite a century's worth of massive destruction, there is still room for the recomposition currently taking place in full view, a process that reveals, most notably, the problematic nature of applying the modern Western concept of "religion" to the Chinese cultural context. ${ }^{(1)}$ The question now is how we can identify, within the current upheavals in Chinese society, phenomena that legitimately attest to a renewal of "religious" Confucianism. The fieldwork conducted in conjunction with this study can provide only an imperfect response to this question. In an environment still profoundly marked by state policy concerning religion, it is best to momentarily suspend use of the familiar categories of the sociology of religion and pay closer empirical attention to a variety of discourses and practices that are ambiguous by virtue of their multiple meanings and the rapid societal changes affecting them.

As an example of this new situation, consider the symptomatic proliferation of the multivocal term xin ("trust"). This value denotes a variety of meanings ranging from "trust" to "belief," and its fading or absence in social intercourse is commonly lamented today.

For example, a worker who left his home in Hubei to work in one of the new industrial loci along the Pearl River Delta decides one day to quit his job with a state-run shoe manufacturer in Dongguan. He opts to take a job in a restaurant run by a young woman who has embraced Confucian ideals. Through study of Confucius's Analects every morning, both on his own and in groups, he finds a source of daily fulfilment.

1. See the concise portrait sketched by Vincent Goossaert and his excellent bibliography in "L'invention des 'religions' dans la Chine moderne," in Anne Cheng (ed), La pensée en Chine aujourd'hui, Paris, Gallimard, 2007, pp. 185-213, ff. 
The working conditions were hard in that factory," he explains, "but the problem wasn't material; in fact, I made more money there. But at that factory all people thought about was money, there was no trust (xin). I'm much happier here... ${ }^{(2)}$

At the other end of the social scale, a Guangdong-based entrepreneur who is equally committed to the notion of a Confucian renewal also brings up the need for trust, both within his business, where employees are encouraged to take the teachings of the classics to heart, and within the larger social and economic environment. ${ }^{(3)}$

In noting the various contexts in which this term comes up, it would be possible to outline a veritable "general economy" of xin that draws its effectiveness from the resources of traditional Chinese culture and the imperatives of the new capitalist society. Thus, one could highlight three possible realms for this collective virtue: the dimension of "trust" expressed in social interactions; the dimension of "credit" praised in economic relations; and the dimension of "creed" that permeates religious relations in general. ${ }^{(4)}$ It is within this context that the concept of "religious," as it applies to some aspects of the current vogue for Confucianism, reveals its specificity but also its limits.

This study will restrict itself to three aspects of a varied religious quest, one that is captured well by the common expression anshen liming, with its emphasis on how finding inner peace implies concern for both personal and collective destiny. ${ }^{(5)}$ To give an idea of the richness of personal experience that claims its roots in today's Confucian religiosity, we will first consider the individual account of a businesswoman who "converted" to Confucianism after a long and complicated spiritual quest. Discerning the meaning of the term "religion" that is implicit to such an example will then require situating it within the context of shifting categories (religion, philosophy, science) that were once accepted as self-evident but which today are being questioned by elites and other groups in society. Finally, in order to give an idea of explicit and deliberate attempts to grant religious Confucianism official and institutional recognition, we will analyse three such efforts that are being pursued according to the logic of Confucianism as a "specific religion," as a "State religion," or as a "civil religion."

\section{"The varieties of religious experience"}

The Goose Lake, a vegetarian restaurant, is distinguished only by its name from the swarm of other commercial estab- lishments that make up the new city of Shenzhen. The only way to find it is through a friend or someone sharing the Confucian commitment of its proprietor, Mrs. D. Visitors are warmly welcomed by a lively woman in her forties who is prepared to relate her spiritual odyssey with a surprising combination of fervour and lucidity.

Her story entails a succession of dramatic events that follow a pattern similar to many religious experiences: that of an initial illusory happiness followed by a downfall, and then discovery of an arduous path towards salvation. Most relevant for the purpose of this study, however, is the role played by Confucianism in the chain of events. ${ }^{\left({ }^{6}\right.}$

Mrs. D. grew up during the time of transition from the Maoist era (at 14, she became a member of the dance troupe of the People's Liberation Army) to the new society inaugurated by Deng Xiaoping's reforms.

I come from Liaoning Province, and I was born into a military family without education. It was a generation that knew only struggle. But what advantage was there to all that, to the struggle between brothers or between those on top and those on the bottom? To this day, my parents are part of the generation that reveres Mao Zedong, the generation whose spiritual life (jingshen shenming) was destroyed, a generation that lacks any peace of mind.

At age 20, she left the army to look for work in various cities. Her enterprising spirit and independence proved a perfect fit for the opportunities offered by the market economy that prospered during the 1990s. Employed as a waitress in a modest restaurant, she rose to become its proprietor, and at 25 joined the envied category of those earning "more than 10,000 renminbi" a month. Yet the easy life led to dissipation and anxiety:

I had all the material things in the world, but my life was a living hell. I went wild, I made lots of mistakes, you know. When one has no education, no religion, no humanity (zuo ren) but lots of money, one can easily go wild. A normal person who commits a crime or

2. Interview, Shenzhen, June 2007.

3. Interview, Guangzhou, June 2006.

4. The analysis of such an "economy of $x i n$ " is the object of a work in progress.

5. On this notion see the collective work Anshen liming yu dongxi wenhua (Anshen liming and Western and Oriental cultures), Hong Kong, Fazhu chubanshe, 1992.

6. Interviews, Shenzhen, June 2007. 
a sin (fanzui) has regrets (chanhui), right? Not me. I couldn't care less. My life was out of control, I was incapable of thinking rationally (lixing de sikao). I figured out that money couldn't solve my problems and I became superstitious (mixin).

Her escape from this period of dereliction came through an encounter with Buddhism, when an initiate led her to understand that she was heading towards her ruin: "It's as if you were dead. You could have a new life but I am not the one who can help you: you need to start off by reading the Buddhist sutras."

For three years my life was governed by Buddhism, and I became different from the people around me. I came to understand that my bad acts (eguo) were the fruit of a bad heart (exin). People can be transformed from living in a state of confusion to attaining a state of understanding by Buddhism. I read the sutras on my own, but because of my life experience I came to understand them. Buddhism is not a religion: it's not a matter of commandments - it's a set of teachings. People ask God for things. You don't ask Buddha for anything. It's a profound teaching focused on achieving enlightenment, on becoming a sage. An ordinary person can become a Buddha. There's no superstition, but rather Buddhism sets in motion a genuine transformation.

This rupture marked the beginning of a new existence that initially bewildered her friends and family.

Today, I have no possessions, no car, no fixed salary. I'm not concerned about money, and my parents still think I'm crazy! I don't care.

However, her discovery of Buddhism was only the first step toward apparent redemption. What she now believes to be her life's definitive orientation emerged through the Confucianism inspired by the teachings of the Taiwanese philosopher Wang Caigui. She first discovered Wang through a series of $\mathrm{CDs}$ promoting the recitation of the Confucian classics that she bought for her daughter. A disciple of the famous philosopher Mou Zongsan, Wang became a major influence on Mrs. D.'s life. She met him in person in 2004 and subsequently devoted herself to spreading Confucian teachings among both children and adults. Her business established recitation courses for children, which began to at- tract members of her staff as well. In addition, many of her clients and their friends have also attended conferences she organises on the virtues of Confucian education. ${ }^{(7)}$

However, her commitment to Confucianism has greatly exceeded her educative efforts. Her meeting with the Taiwanese thinker convinced her that Confucian teaching is destined for humanity as a whole (renlei de mingyun):

\section{If Confucianism were just one more set of teachings (yi men), just another ideology, it wouldn't be worth studying. It is not just for scholars, it is the path by which all of humanity can find refuge (renlei guisu de fangxiang). There are no racial or religious borders: Confucianism can solve the problems of the entire world...}

Despite its unique aspects, Mrs. D.'s experience raises certain questions concerning the distinctly religious dimension of Confucianism. The first thing to point out is that her adherence to Confucianism can only be understood as a kind of conversion. This deliberate embrace of the ideals of Confucian wisdom was preceded by a period of crisis and breakdown. It came about only after a long spiritual journey that began with "superstition" (she remains silent about the details) followed by a drawing on the resources of Buddhism. This kind of odyssey is relatively rare among businesspeople who turn to Confucianism. We mentioned elsewhere the example in Zhuhai of the "Pinghe academy," which provided a communal lifestyle to a small group of initiates and engendered a network of followers. ${ }^{(8)}$ Its founder and director was a prosperous businessman whose enthusiasm for Confucianism followed a period of time spent in the United States, where he embraced the Baha'i faith. However, it is much more common for businesspeople to develop an interest in Confucianism to complement or enhance their professional striving rather than as a refuge in the wake of personal crisis. For some, studying the Confucian classics and attending academic conferences represents a crowning achievement of a life of business success, one that satisfies both a desire for more intellectual pursuits and aspirations towards less materialistic values. For others, a more occasional involvement offers the chance to display one's cultural and social capital. We also need to note the special role Buddhism played in Mrs. D.'s story. This aspect of her experience was not re-

7. See Sébastien Billioud and Joël Thoraval, "Jiaohua: The Confucian Revival Today as an Educative Project," China Perspectives, no. 2007/4, p. 14.

8. Ibid, p. 13 . 
jected but rather amplified and reoriented by her acceptance of Confucianism. From her perspective, it's a matter of restoring the common spirit underlying both traditions while highlighting the superiority of Confucianism:

\section{We shouldn't exaggerate the difference between the way of the bodhisattva (pusa) and that of the sage (shengxian). They're just two words to designate the same thing. The two teachings are rooted in real life. When one becomes a bodhisattva, what else can be the focus of one's attention? It's not a question of worrying only about oneself, of trying to escape life's vicissitudes (fannao) or seeking a Western Paradise (Xitian). It's the same with Confucianism. Lots of people study for their own benefit (weile geren), for academic reasons (xueshu). That's the attitude of a petty person (xiaoren); those people are phoney Con- fucians (ruzhe). You can't turn your back on society...}

Such a perspective combines some very ancient elements with more contemporary preoccupations. Without dwelling on the history of the symbiotic yet equally tense relations between the two traditions since the neo-Confucian reform of the Song, it is well known how important Buddhism was to the refashioning of a modern Confucianism at the end of the Empire and during the Republican era. At a time when the institutional structures of Confucianism were gradually being dismantled, many scholars saw in Buddhism the only possible counterweight to the power of the West because of the complexity of its theoretical constructions and its involvement in charitable activities. Occasionally, this doctrine of non-violence could also, paradoxically, provide the basis for nationalistic mobilisation. ${ }^{(9)}$ Moreover, Buddhism could constitute an individual response to the existential crises engendered by social upheaval without contradicting a Confucian commitment towards society. In fact, through her references to Liang Shuming, our restaurant owner is fully aware of aligning herself with this dual heritage. ${ }^{(10)}$

Since the beginning of the century, additional factors favouring symbiosis between Buddhism and Confucianism have become clear. On the mainland, many of the websites and publications propagating the Confucian classics are actually the work of Buddhists. Such an alliance results from a combination of conviction and calculus: conviction, because of a belief in adapting instruction to match the level of understanding of the potential public (an example being the works of the Taiwanese master Nan Huaijin $\left.{ }^{(I I)}\right)$; and calculus, because Buddhism's recognition as an official religion theoret- ically precludes all attempts at proselytising. In presenting itself with a Confucian face, Buddhist teachings can appear more like a call to greater wisdom and morality in the spirit of traditional national culture.

Mrs. D.'s experience raises another question, one concerning the legitimisation of the teachings that have transformed her life. This question brings the particular and ambiguous role of the master to the fore. Mrs. D. tends minimise that role, stressing Confucianism as a process of self-liberation:

The big mistake people make studying Buddhism is to want to escape the world; the big mistake when it comes to Confucianism is to claim to be a master. Until one gets past these temptations, there is no possibility of assimilating the true doctrine (zhenzheng de xuewen). Obeying one's teacher is not the important thing; what's most important is following one's "original nature" (benxin). That is the greatness of Confucianism (rujia de weida).

As will become apparent once we consider the use of the term "religion," this attitude can be explained in part by the desire not to conflate Confucian teaching (jiao) with the conception of a religious institution (zongilao) introduced by the Christian West. Just as one does not "obey" a God or a Buddha, one does not "obey" a master whose role is only to facilitate one's own self-realisation. Such theoretical downplaying of the importance of a master is the flip side of a practical valourisation that can take on extreme forms. Since meeting Wang Caigui, Mrs. D. has remained in regular contact with her teacher. This long-distance communication with the master involves for her more than asking for advice over the telephone or by email:

Our communication is brief, but every time we do get in touch with each other, I have the feeling that it is a matter of reciprocal resonance (xiangying). That's something I can feel during meditation. The master has a transcendent existence (chaoyue de cunzai) he's always present...

9. See in particular Chan Sin-wai, Buddhism in Late Ch'ing Political Thought, Hong Kong, Chinese University Press, 1985.

10. For an explanation by Liang Shuming of the relations between Confucianism and Buddhism, cf. the interview with Wang Zongyu, "Shi rujia haishi fojia?" (Confucian or Buddhist?), Zhongguo wenhua yu Zongguo zhexue, Beijing, Dongfang chubanshe, 1986, pp. 560-565.

11. Born in Wenzhou in 1918, Nan Huaijin had a career in the military during the Republican era before devoting himself to the study of different schools of Buddhism. He left for Taiwan in 1949, and since 1990 has maintained business and teaching activities on the mainland 


\section{Articles}

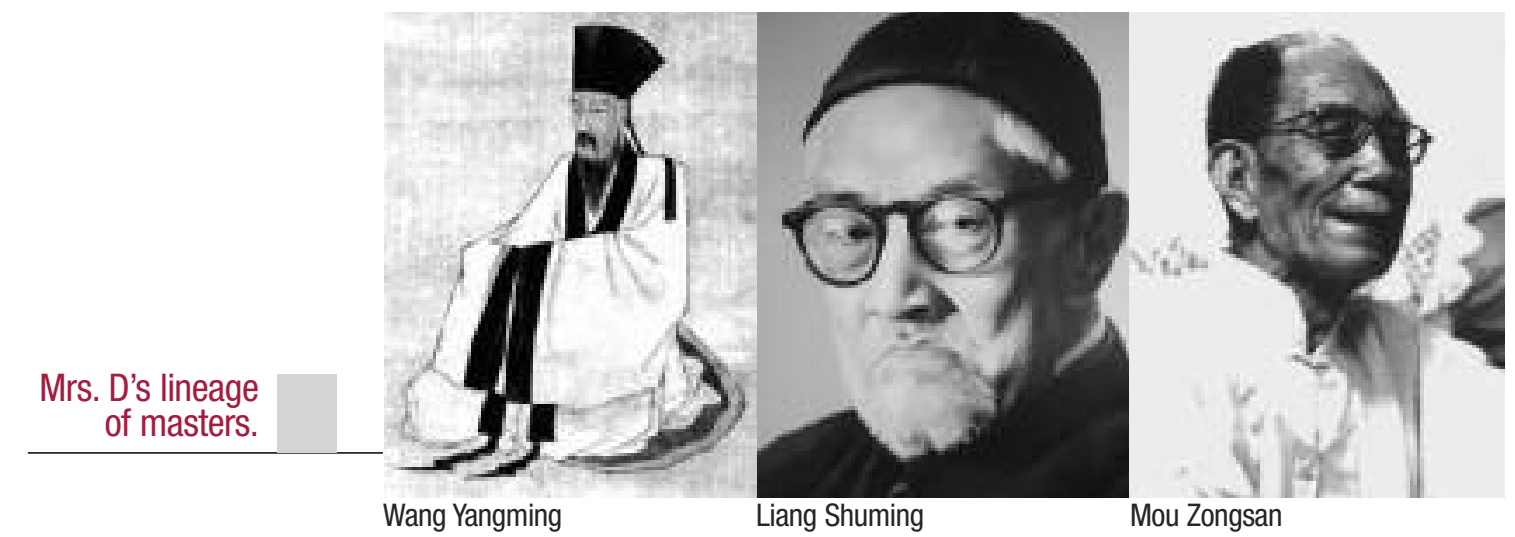

This form of mediation on the master's part is probably why Mrs. D. attributes such efficacy to Confucianism. Essentially, her encounter with Buddhism was as an autodidact, reading sutras and commentaries by unknown masters on her own and leading an existence that set her apart from her immediate peers. However, the intercession of a living Confucian master provides both confirmation of her spiritual vocation ("you have attained the necessary level or jingjie") and the possibility of situating herself within a lineage of masters whose legitimacy stemmed from association with past and living sages. Asked about such a lineage, she mentions most notably Wang Yangming, Liang Shuming, Mou Zongsan, and her present master. It is clear that she perceives a continuum between a true master and the sage whose life is an embodiment of Confucian teaching.

A final element is the horizon of expectation that the teaching instils among initiates. There are certainly different degrees of initiation between restaurant employees who are grateful for the solace derived from their daily reading of the classics and the wealthier parents who are ready to pull their kids out of the normal school system in order to place them within a new community where education is conceived of as a true "incorporation" of the deeper meaning of the Confucian classics. ${ }^{(12)}$ It is among this minority of followers that devotion is most likely to reach a messianic pitch. This utopian perspective expresses itself in a threefold manner. One finds, first of all, more reverence for the master than for the head of the family, an affirmation of the greater legitimacy of shidao (way of the master) than xiaodao (filial piety): "One's teacher is more important than one's parents; one's parents give the gift of life, but one's teacher gives the gift of wisdom." Such reverence for the master additionally engenders a sentiment of particular urgency, given the discontinuity introduced by the communist and post-communist eras. "Today our master is 57 years old. If we are unable to educate our children according to his principles, the future of Confucianism is at risk." The voluntary relinquishing of parental authority over children receiving the new education leads to the opening of a glorious horizon: "They are not our children, they are the nation's children (minzu), humanity's children (renlei)." This vision includes a trans-generational dream: "Children who have studied the classics will intermarry and raise their own children." These moments of exaltation reveal a comprehensive vision of humanity being revitalised thanks to what could be referred to as the production of saints and sages. It is all the more remarkable since, despite the warm-heartedness of the actions pursued, there is a permanent denouncing to parents of the prevailing societal pollution (wuran) that irremediably poisons both the predominant educational system and mass communication, and from which children must be shielded.

While there is always the risk of this type of movement turning into a sect, it is seldom found among the diverse groups calling for a Confucian revival today.

\section{Appropriations of and challenges to modern categorisation}

The only way to understand the as yet embryonic re-emergence of a Confucianism claiming to be religious is to see how it fits into an already ancient history in which the modern Western notion of "religion" plays a fundamental role in the redefinition of modern Chinese civilisation. This debate has its own form of prehistory, beginning with the confrontation between imperial China and Europe from the sixteenth to the eighteenth centuries, during which the problem of the religious specificity of Confucianism was already an issue: the "Rites Controversy," the product of the audacious interpretations of Jesuit missionaries, stands as an early testimony to the complex and ambivalent dialogue that characterised early contact between China and the West. The dramatic nature of the transformations at the end of the Manchu Dynasty, however, is embodied in the context of Western imperialism and the supremacy of a type of Western knowledge that the Chinese feel obliged to embrace for the sake of their own survival. It

12. On the role of the body, children, and the people in this education, see Sébastien Billioud and Joël Thoraval, "Jiaohua: The Confucian Revival Today as an Educative Project," op.cit., pp. 14-21. 
is not possible within the limits of this study to comprehensively review this complex history; we can only recall a few essential characteristics that still have consequences today.

\section{A teaching in search of categories}

It is striking how the notion of "religion," previously unknown in China, was introduced as part of an aggregate of concepts - "religion," "science," "politics," "fine arts," "literature," "philosophy" - constituting the fundamental structure of European culture and society. The only way to define one concept was in terms of its standing relative to all the others. Their introduction over a remarkably short period of time, thanks primarily to the mediation of Meiji era Japan, required a wholesale reorganisation of the cultural and social order in China, including the destruction and reinvention of entire branches of Chinese civilisation. At the risk of being too schematic, it is possible to reconstruct - in a logical rather than chronological fashion, since the steps of this evolution overlap - the different stages of this confrontation between Confucian heritage and the new category of religion.

The first period witnessed a determined resistance, stemming from the allegiance of the imperial state and the literati to Confucian tradition and the indigenous and inclusive category of jiao (teaching), as opposed to the more exclusive neologism zongjiao, the translation of the European notion of "organised religion." It is too infrequently acknowledged that what this confrontation particularly called into question was not the general idea of "Western religion," but rather the modern category of religion, which is the fruit of a progressively secularised Europe. Whereas the Emperor Yongzhen, when faced with missionary activity during the eighteenth century, believed he could situate Christian monotheism along with Confucianism within the overall Chinese category of jiao (teaching), the imperial state at the turn of the twentieth century was challenged in its decline by a set of institutions, whether churches, religious sects, institutions of higher learning and universities, or even political movements, that were differentiated and relatively autonomous in terms of their respective values. The ancient Confucian teaching that ritualistically encompassed conceptions of cosmic and political orders as well as prescriptions of ethical and social norms, confronted a more narrowly determined institutional framework: the European religious subsystem, restructured within a social context characterised by secularisation and the new democratic horizon.

By the end of the Empire there was a growing distinction between what was considered a matter of "knowledge" (xue) and what concerned "teaching" (jiao), which, because of the growing importance of Western science and technology, began to take on a more restrictive meaning, primarily linked to the fundamental values of Chinese tradition. ${ }^{(13)}$ In this light, the last years of the imperial era witnessed a brief and striking differentiation of the cultural and religious dimensions of ancient heritage. Whereas the suppression of the exam system in 1905 marked the end of a crucial institution of the Confucian cultural order, and by the same token, the demise of certain forms of "learning," Confucianism paradoxically took on a new pre-eminence as a kind of state religion (guojiao) through the unprecedented promotion of the cult of Confucius to a status equal to the high imperial ritual worship of Heaven and Earth.

After 1911, the creation of the Republic inevitably created a quandary for defenders of the traditional inclusive notion of teaching (baojiao) such as Kang Youwei. Ambiguity had still been an acceptable possibility when Liang Qichao, in exile in Japan, defended the reform projects of his mentor, promoted to the rank of a Confucian Luther. For a brief time it remained credible to argue that the person who was primarily responsible for introducing to China the Japanese neologism for religion (shukyô) used it in a way that preserved the more comprehensive ancient concept of jiao. The point was less to highlight Kang's presumed embrace of religion than to justify his complete transformation of Confucianism into a set of worldly goals (egalitarianism, progressivism, altruism, etc.). ${ }^{(14)}$ If such ambiguity became increasingly untenable, it was not only because of an evolution of the intellectual debate - in fact, since 1902 Liang Qichao had already refused to consider Confucius a religious figure $^{(15)}$ - but mainly due to the new political regime. Henceforth, the drafting of a republican constitution required determining in precise legal terms the future status of Confucianism in China: was it a doctrine capable of becoming a state religion? The constitutional debates, overshadowed by political turmoil, only reached a compromise formula that was soon made irrelevant by the more radical secularism in-

13. The proposition by Wang Zhao, who was, in fact, an adversary of Kang Youwei, to create in 1898 a ministry of Confucian teaching (jiaobu) distinct from the ministry of education (xuebu) already provides an illustration of this situation. See Hsi-yuan Chen, Confucianism Encounters Religion: The Formation of Religious Discourse and the Confucian Movement in Modern China, Doctoral thesis in History and East Asian Languages, Harvard, UMI Microform 9936192, 1999, p. 89.

14. Ibid., p. 62

15. On the complex evolution of Liang Qiachao's position on religion, see Marianne Bastid-Bruguière, "Liang Qichao yu xongjiao wenti" (Liang Qichao and the problem of religion), in Hazama Naoki (ed), Liang Qichao, Meiji Riben, Xifang (Liang Qichao, Meiji Japan, and the West), 2001, Beijing, Shehui kexue wenxian chubanshe, pp. 400-457. 


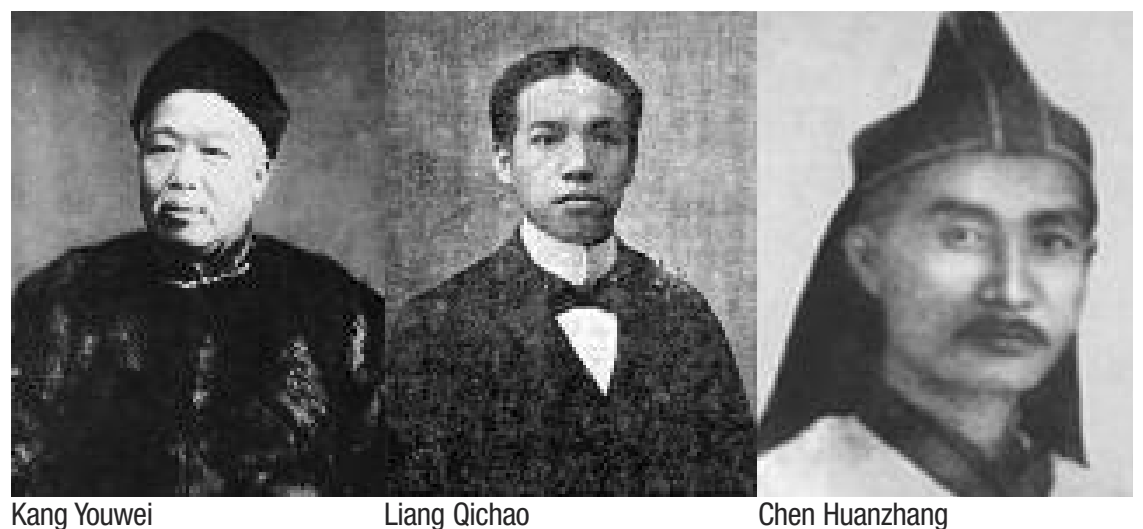

troduced by both the Nationalist and the Communist parties. ${ }^{(16)}$

It is during this period that the term Kongjiao, already in circulation at the end of the Empire, definitively began to designate what could be called a "Confucian religion," complete with the reference to Confucius. Ironically, the Western invention of "Confucianism" by nineteenth century scholars using the universal religions of Jesus and Mohammed as models finally became a reality on Chinese soil. Founded in 1912, the Confucian Association (Kongjiaohui) grew rapidly during the first years of the Republic under the leadership of one of Kang Youwei's disciples, Chen Huanzhang (1880-1933): two years after its creation there were 132 branches both in and outside China. ${ }^{(17)}$ The Confucian Association engaged in a kind of mimetic rivalry with Protestantism through its attempts to concoct ritual equivalents such as vestments, symbols, religious holidays, and weekly religious services that assembled what were referred to as believers (jiaotu). ${ }^{(18)}$

From this period on, affirming a Confucian religion within Chinese political space entailed providing answers to three questions that would re-emerge in different terms at the beginning of the twenty-first century: How to reconcile aspiration towards the pre-eminence of a state religion with the necessity of freedom of religion? How to ensure that any promotion of Confucianism does not weaken the unity of the new nation, given the religious traditions of certain non-Han groups (Tibetan Buddhism, Islam)? What sort of public places of worship could fill the void after the destruction or transformation of previously essential institutions such as the Temples of Culture and the ancient academies (shuyuan)? One word should be said about this final concern, since it actually reflects some sort of "prejudice" of the educated elite regarding the possibility of disseminating Confucianism among the masses, the effects of which were felt throughout the twentieth century.

Indeed, in the1920s, a common preoccupation of the learned class concerning the dissemination of "religious Confucianism" was the fear that the Chinese masses might not be up to it. This is more than a little paradoxi$\mathrm{cal}$, given the way Confucianism permeated society during centuries of imperial rule. ${ }^{(19)}$ The anxiety of the elites grew along with a certain nostalgia for the traditional institutions they frequented - the temples and academies that once legitimated the shidafu's dominant position in society. As their sociological status underwent a progressive change throughout the new Republican order, these elites became politicians, intellectuals, or academics, and henceforth paid only secondary attention to the vast universe of popular worship in ancestral temples or local cultural associations. But was there not significant food for thought in the vitality of the practices of the ancestral citang, where the ritual classics continued to be interpreted by the most educated members of the local community? This distancing of itself from the ordinary practices centered on kinship by an elite growing progressively urban and orienting itself towards a national horizon combined with a traditional wariness toward folk beliefs considered "superstitious" or heretical. Consequently, the new Confucian religion committed itself to regaining control of and restructuring the "de-Confucianised" rural world in order to protect it from the seductive appeal of Christian churches and sects, which were particularly active in edu-

16. Far from endorsing proposals for the establishment of Confucianism as a state religion (guojia), article 11 of the 1923 constitution limited itself to indicating, in vague terms, that the citizens of the Republic of China enjoy the "freedom to revere Confucius and to practice any religion...in conformity with the law." Hsi-yuan Chen, Confucianism Encounters Religion, op. cit., p. 187.

17. On Chen Huanzhang's ideas, see Nicolas Zufferey, "Chen Huanzhang et l'invention d'une religion confucianiste au début de l'époque républicaine," and on the context of this discussion, see V. Goossaert, "Les mutations de la religion confucianiste, 1898-1937," in Flora Blanchon and Rang-Ri Park-Barjot (ed), Le nouvel âge de Confucius, Paris, Presses Universitaires de Paris-Sorbonne, 2007, pp. 173-188,163-172.

18. Gan Chunsong emphasises the influence that Christianity was able to have on the development and transformation of "indigenous religions" and particularly Confucianism. He also provides more detail on the organisation of this Confucian religion. Gan Chunsong, "Cong Kang Youwei dao Chen Huanzhang" (From Kang Youwei to Chen Huanzhang) in Gan Chunsong (ed), Rujia, rujiao, yu zhongguo zhidu ziyuan, Nanchang, Jiangxi chuban jituan, 2007, p. 35 ff and pp. 75-76.

19. Thus Yan Fu observes that, despite its hold on society since the Han Dynasty, Confucianism never became a popular faith: "Yan Fu noted that "most females and children know about the ideas of heaven, hell, Buddha and Yama' but none of them has ever heard the names of any of Confucius's disciples." Chen Hsi-yuan, Confucianism Encounters Religion, op.cit., p. 85. 
cation and charitable work. ${ }^{(20)}$ To a certain extent, it was not until the emergence of another intellectual community, the brilliant Chinese school of sociology and anthropology of the 1930s and 1940s, that the panoply of Chinese beliefs and practices could be reconstituted in a coherent fashion, independent of modern policies concerning "beliefs," "religion," and "superstition."

During this second period of encounter between Confucian heritage and the new category of religion, the failure of a religious Confucianism based on Western models is linked to the triumph throughout the 1920s of an alternative Western conceptual category, that of science (kexue). Indeed, it is on this category that a significant portion of the new intelligentsia began increasingly to rely in evaluating China's cultural heritage. ${ }^{(21)} \mathrm{A}$ debate, launched most notably by figures of the May Fourth Movement in their review Xin qingnian, resulted in a denial of any legitimate role for religion in the new China, whether in a Christian or newfound Confucian form, all in the name of science. By 1930, the Confucian Association was no longer attracting new elites, and Chen Huanzhang left the mainland for Hong Kong, where his movement was perpetuated to the present. Moreover, as Zheng Jiadong has pointed out, the majority of specialised publications avoided discussing Confucianism in terms of "religion" until 1950. ${ }^{(22)}$ Henceforth the majority of academic publications relied on secular terminology to characterise Confucianism, preferring terms such as "school" (rujia) or "knowledge" (ruxue). As for the "religion of Confucius," it fell into a lasting decline.

The anti-religious polemic engendered yet a third turn in the conceptualisation of Confucianism, one that saw the ascendance of the category of "philosophy" (zhexue). Inspired by the Meiji era example of Inoue Tetsujirô and his peers, leading scholars such as Wang Guowei already by the end of the imperial era considered "philosophy" the Western conceptual category most applicable to traditional Confucian scholarship. A proliferation of modern universities, leading to the establishment of academic exchanges with Europe and the United States along with a confrontation with the great Western philosophical systems, gave birth to a golden age of new "Chinese philosophy," one most famously embodied in the work of Feng Youlan, a scholar capable of both systematising and conceptualising Confucian doctrine while at the same time tracing back its genealogy. However, the most significant flowering of "philosophical Confucianism" occurred in the relative exile of Hong Kong and Taiwan in the work of major thinkers such as Mou Zongsan. It was only half a century later that that the impoverishment of the ancient no- tion of "teaching" through transformation into an academic discipline would become fully apparent.

A veil of amnesia shrouded the complexity of this evolution as a result of the virulent anti-Confucianism of the Maoist era that reached its most convulsive stage during the Cultural Revolution. When acknowledged at all, Confucius was referred to simply as an "educator" (jiaoyujia). Thus it fell upon young historians of the post-Mao era to resurrect the memory of the three key phases of contemporary Confucianism's development that we have just presented: the resistance to foreign influence mounted in the name of Confucianism as a comprehensive teaching (jiao) fusing diverse dimensions of experience; the temptation to concoct a fully ecclesiastic Confucianism (Kongjiao); and finally, what can be characterised as a formal withdrawal into the "consolation of philosophy," seeking refuge in allegiance to a system of abstractions in the name of an ideal of wisdom.

\section{Fluidity reclaimed: The questioning of twentieth century categorisation}

Beginning in the 1980s, "Confucianism" progressively acquired a new visibility. The traditional concept of comprehensive teaching (jiao), however, resurfaced only in a fragmented and mutilated form in the erudite writings of the academic world after 30 years of radical critique. Even though the policy of reform and opening did allow for a gradual reappropriation of Confucian intellectual developments outside the mainland, particularly from Hong Kong and Taiwan, the task of reconstruction nevertheless remained confined to the world of historians, literary critics, and philosophers in academia. Most notably, it was divorced from developments at the village level, where there was a gradual reestablishment, despite formal illegality, of rituals linked to ancestral temples and local communities. Thus, at the beginning of the 1990s, in the wake of the events of Tiananmen Square, it came as a surprise when a young anthropologist from Shanghai, Qian Hang, rediscovered the vitality of practices associated with ancestor worship in the southern provinces. He had originally been sent by the Shanghai Academy of Social Sciences to investigate the persistence of

20. Chen Hsi-yuan also points out that Chen Huanzhang's program is oriented towards youth, workers and merchants, women, and villages. Ibid., pp. 223-224. Similar ambitions are common among advocates of the current Confucian revival.

21. D.W.Y. Kwok, Scientism in Chinese Thought, 1900-1950, New Haven, Yale University Press, 1965.

22. On this problem, see Zheng Jiadong, "Rujia sixiang de zongjiaoxing wenti" (The problem of the religious dimension of Confucian thought), in Dangdai xinruxue lunheng (Essays on Contemporary NeoConfucianism), 1995, Taipei, Guiguan, pp. 171-233. 
disruptive "feudal" customs such as xiedou, traditional vendettas between rival lineage groups. Instead, Qian reported on constructive gatherings of clan elders and local officials in ancestral temples to discuss problems of daily village life that eluded solution through socialist legislation (for example, questions concerning property and the common use of ancient citang: are these rights assigned to the entire village or to descendants of the same ancestor?). He concluded that this form of conflict resolution was more peaceful and reasonable due to the vitality of cultural traditions preserved by educated villagers. These practices, which constituted some remnants of "popular Confucianism," remained largely anthropological curiosities: urban academics, in their fixation on learned analyses of texts and discussion of values and concepts derived from traditional culture, were mostly oblivious to these village-level phenomena. ${ }^{(23)}$

The first years of the new century, on the other hand, have sparked a growing cross- fertilisation of Chinese society as a result of rapid development, greater social mobility, and the importance of new means of communication. An increased fluidity of exchange, both material and intellectual, has triggered a re-examination of received categories of thought. The institutionalised categories that officially delineated the remnants of "Confucian" tradition have taken on an unnatural and even problematic status. This relative weakening of basic conceptual foundations is the result of a double process of scrutiny taking place simultaneously at the summit and grassroots level of society. On the one hand, certain academic elites question the legitimacy of the disciplinary division that has fragmented the ancient "national studies" (guoxue) to the point that their meaning and internal coherence are rendered unintelligible; for example, the creation of a "Guoxueyuan" at the People's University in 2002 led to debate concerning the perverse effects of scientific specialisation based on the Western model that prevents an approach to texts that simultaneously mobilises literary, historical, and philosophical perspectives. ${ }^{(24)}$ On the other hand, a growing number of movements promote a "Confucian revival" at the grassroots level. While these groups often resort to vague and uncertain language and practices, they are still casting off the old academic classifications.

A clearer understanding of the apparently religious dimension of the current "popular Confucianism" (minjian rujia) requires examining specific examples. Indeed, the new meanings for the category of "religion" will become clearer by comparing a few cases that demonstrate an unexpected use of the two contemporary categories of "philosophy" and "science." If these categories merit our attention, it is due not only to their classificatory function, but also to their performative role. They do not merely differentiate the content of a pre-existing Confucian teaching; they also actively modify the reality they qualify. Treating Confucianism as either religion, philosophy, or knowledge naturally transforms it into as many new dimensions. Categorisation interests us because it is synonymous with practice and the demand for institutions.

Elsewhere we have discussed the problems and even contradictions generated during the twentieth century by the creation of "Confucian philosophy" based on the European philosophical model. The creation of remarkable philosophical systems by "contemporary neo-Confucian" thinkers who, like Mou Zongsan, worked mainly in university settings, resulted in an intellectualisation of traditional teachings. Whereas the old Confucian "academies" ( shuyuan) focused as much on the body as on the mind, the "contemporary neo-Confucians" fashioned metaphysical systems to rival European speculative philosophy, while amputating the physical and symbolic aspects of their tradition. Self-transformation and sagehood remained a central topic of the new philosophical Confucianism, but these ideals were somehow divorced from the means of their realisation: in becoming pure philosophy cultivated in the context of the modern university, the neo-Confucian message of wisdom was at least partially stripped of its conditions (cultural or anthropological) of possibility. This academic appropriation of Confucianism during the twentieth century was resisted by scholars such as Ma Yifu or Liang Shuming, who in their own way remained faithful to the ideals of the traditional academies. In that respect, we have evoked the emergence of a veritable "Confucian anti-philosophy." ${ }^{25)}$ At the beginning of the twenty-first century, this development has become the focus of renewed interest, even within mainstream philosophical circles.

Observation of the diverse "popular" movements (minjian) reveals some unexpected developments taking place outside of the usual academic framework. Returning to the example

23. Qian Hang, Chuantong yu zhuanxing: Jiangxi Qinhe nongcun zongzu xingtai (Tradition and transformation: Village lineage structures in Qinhe, Jiangxi Province), 1995, Shanghai shehui kexueyuan chubanshe. On this particular example and its importance, cf. Joël Thoraval, "The Anthropologist and the Question of the 'Visibility' of Confucianism in Contemporary Chinese Society," China Perspectives, 23 (1999), pp. 65-73.

24. See Sébastien Billioud and Joël Thoraval, "Jiaohua: The Confucian Revival Today as an Educative Project," op.cit., pp. 8-10.

25. Joël Thoraval, "Confucian experience and philosophical discourse: Reflections on some aporiae in contemporary neo-Confucianism," China Perspectives, no. 42, July-August, 2002, pp. 62-81; "Sur la transformation de la pensée néo-confucéene en discours philosophique moderne," ExtrêmeOrient, Extrême Occident, 27 (2005), pp. 91-119. 
of the restaurant owner in Shenzhen cited above, we can add that her missionary work is not limited to reading the Confucian classics or following the teachings of her Taiwanese mentor. Her library contains most of the wellknown works by Mou Zongsan, which she pushes herself to read despite her lack of philosophical training. However, her relationship with these texts is not one of a student studying an illustrious philosopher. "Master Mou is a sage (shengxian), not a scholar (xuezhe). He indicates the way for all of humanity (renlei de fangxiang)." Aware of having indirectly embraced a prestigious line of descent stretching back to the sages of antiquity and to major Confucian figures of the Song and Ming dynasties, as noted above, Mrs. D. fuses her study of difficult texts such as the Xinti yu xingti (Constitutive Mind and Constitutive Nature) with her personal practice of self-transformation and proselytism. For the authors of this study, who have both written on Mou Zongsan in the past, it is a genuinely strange experience to be confronted with such a non-academic and unconventional interpretation of writings that, by reputation, represent the most rigorously philosophical form of modern Confucianism, impregnated as they are by both the logic of the Anglo-Saxon tradition and the philosophy of Kant. What this experience makes plain is how philosophical texts can be read in non-philosophical ways. Despite its progressive abstraction into pure "metaphysics," Mou Zongsan's work reveals itself to be sufficiently inspirational as a radical call to wisdom, akin to the school of heart and mind (xinxue) and reinforced by concepts from Tiantai Buddhism that are open to unexpected appropriations defying the norms of the academic world.

This example is far from unique. We can cite another of someone who yearns for a Confucian revival among ordinary people and remains outside the university sphere while having been influenced by it. A resident of Jiangsu province, M. L. went to Shandong along with activists from other provinces, whom he met online or through third parties, to participate in ceremonies commemorating Confucius's birthday, rituals intended to reflect popular religious practices as opposed to the official celebration organised in the Temple of Confucius in Qufu. Thus, dressed in Ming dynasty garb, he officiated at a service in nearby Zoucheng at the temple dedicated to Mengzi, the Yashengmiao, along with others hoping to revive traditional ritual practices. ${ }^{(26)}$ While he has never had the chance to be a scholar, M.L. has deepened his understanding of the classics on his own thanks to the guidance of Luo Yijun, a well-known Shanghai intellectual and disciple of Mou Zongsan. ${ }^{(27)}$ M.L. is ac- tive back home in the movement led by Wang Caigui to teach children the classics through recitation. He also tries to get young people to read philosophical works by Mou Zongsan. His approach is to insist upon the close link between learning a text and personal practice:

\section{When one reads Mou Zongsan, one must come to a} unity of reading and effort (gongfu). One must not read like so many professors, who read in a unilateral (pianmian) way. You can't read Mou like you read Kant. Of course, Mou is influenced by Kant, but his own thought remains perfectly in tune with the lixue of the Song and Ming dynasties.

M.L. does not hesitate to criticise the interpretations of famous scholars in Taiwan, professors "who no longer understand much because of the Anglo-Saxon influence on the Chinese education system." ${ }^{(28)} \mathrm{He}$ deliberately keeps his distance from the academic world for the sake of self-cultivation, popular education, and ritual practice.

Examples such as these reveal the uncertain and fluid nature of categories such as "philosophy" within the new social space appropriating Confucianism. Despite their relatively limited scope, these phenomena suggest how change can occur in diverging directions: whereas becoming a form of philosophy promised a unique means of "modernising" Confucianism during the last century, different orientations are no longer unthinkable today, and the ancient "philosophical" spirit (and accompanying practices) can re-emerge and be transformed, or retransformed, into a "religious" one.

The new "Confucianism" that is emerging in certain urban milieus is also challenging the categorisations adopted from the West in other ways. If "philosophy" seemed to offer Confucianism a position of refuge during the interwar period until it could become the object of diverse re-appropriations, most notably religious ones, more recently, the category of "science" has undergone equally unexpected transformations.

The particular case that will concern us below is an effort to ground Confucianism in a scientific or meta-scientific vision of the world. This development can be situated in many respects within a context that also stirred up the "qigong fever"

\section{An upcoming article will examine the question of rites and ceremonies today}

27. This connection is not pure form: Luo Yijun was able to come to Hong Kong at the end of Mou Zongsan's life and "receive recognition as a disciple" (personal communication, 1997). On Luo Yijun, see John Makeham, Lost Soul: "Confucianism" in Contemporary Chinese Academic Discourse, Cambridge, Harvard University Press, 2008, pp. 252-254.

28. Interview, Qufu, October 2007. 
so well described by David Palmer. ${ }^{(29)}$ Three factors converge in this context: the importance of an official conception of "science" that was dominated by ideology while "Mao Zedong Thought" prevailed; the rediscovery, under chaotic conditions, of knowledge, creeds, and practices rooted in Chinese tradition; and the rise of cultural nationalism resulting from contemporary globalisation and a perceived rivalry with the West, an entity sometimes more imaginary than real. While the examples cited above show the reappropriation of philosophical texts as part of a desire for self-realisation and redemption of the world, the case to be explored below illustrates the recovery of the wisdom of the ancient sages via consideration of the most modern physical science: the ultimately "religious" vocation of Confucianism is not to be discerned beyond the worldly path but instead within the very heart of the most radical forms of scientific inquiry.

Born into a family of workers, 37-year-old M.W. studied physics at Peking University and never stopped wondering about a question that official ideology left unresolved: how is it possible for great physicists to believe in God? What is the dimension of reality that existing forms of science appear unable to account for? These questions led to him to leave for the United States after finishing his studies, but his brief stay let him unsatisfied. Upon returning to China and meeting a professor who was a specialist in forest management, but who in his spare time worked on an annotated version of Confucian texts, Mr. W.'s discovery of the Chinese classics convinced him that he had at last found some answers. The crux of the matter was neither science nor Chinese culture per se, but the prevailing way in which they were being interpreted in universities. What was necessary was to rethink the foundations of Confucianism in light of the most recent developments of physical science in order to find common inspiration.

As a result, the program of the academy that Mr. W. intends to create (at present the academy only exists virtually under the name Junde shuyuan, the "Academy of Eminent Virtue") is touted on several websites in the following terms: "Since the second half of the twentieth century, humanity has been faced with serious new problems that have revealed the limits and defects of Western knowledge. These shortcomings can be remedied through the rich resources of the principal pillar of Chinese civilisation, Confucianism." Yet in order to do this, it is necessary, according to Mr. W., to distinguish three major orientations within Confucianism, inspired by the famous "eight propositions" (bamu) enunciated in the classic text The Great Learning, which enumerate the progressive steps toward wisdom, from self-discipline to ordering family life to establishing peace in the universe. ${ }^{(30)}$ Essentially, these propositions define, respectively, a "realist" Confucianism oriented towards things (wuxing ruxue) in the hope of increasing knowledge, a "moral" Confucianism oriented towards the heart/mind (xinxing ruxue) as well as ethical and religious development, and a "communitarian" Confucianism oriented toward the group (qunxing ruxue) and the creation of a harmonious world. The "realist" orientation is the one that can provide the foundation for a Confucian reconstruction once its "scientific" inspiration is taken into account, even if the "things" $(w u)$ in question are not just material objects but also their relations with humans. Thus, "the investigation of things" (gewu) in The Great Learning designates the experimental study of phenomena; "the extension of knowledge" (zhizhi) reflects a concern for achieving a scientific and ontological synthesis; and "making one's intentions sincere" (chengyi) describes the state of mind of the scientist who is dedicated to rigorous critical thought. ${ }^{(31)}$ While the effort of self-transformation called for in the Confucian classic appears reduced to an exclusively realistic and scientific dimension, it is a fairly peculiar science.

The Confucianism oriented towards things (wuxing), Mr. W. explains, is of the same spirit as Ilya Prigogine's new physical science. It's already a science of complexity (fuza kexue). This approach is not that of ordinary science. It is already apparent in the spirit of Chinese medicine, with its reliance on yin and yang, and the five elements (yinyang wuxing). This form of Confucianism is already post-Newtonian in the same sense that Prigogine's work is. ${ }^{(32)}$

The emphasis placed on the interaction of man and nature,

29. Although based on traditional corporal techniques, the movements that develop in Communist China under the term qigong (designating the efficacy of respiration) takes on therapeutic then religious aspects before becoming a political threat. They also posses a very significant "scientific" dimension, since scientists such as the well-known atomist Qian Xuesen saw in qigong a scientific revoIution representing a precious Chinese contribution to modern science before the Communist authorities condemned the program after 1995. Cf. David Palmer, Qigong Fever, Body, Science and Utopia in China, New York, Columbia University Press, 2007, pp. 102-135.

30. The Great Learning posits that "It is by investigating things that knowledge is being extended to the utmost. Knowledge once extended, intention becomes sincere. Once intention is sincere, the heart is rectified. The heart being rectified, the self is cultivated. The self being cultivated, one's family is regulated. One's family being regulated, one's State is rightly governed. And when States are rightly governed, the Great Peace prevails across the universe." See: "Daxue" (The Great Learning), in Zhuzi quanti (Complete works of Zhuxi), Shanghai, Shanghai guji chubanshe, 2002, vol. 6, p. 17.

31. See the Tianya Forum website: http://www.tianya.cn/publicforum/Content/no100/1/20099.shtml. 32. Interview, Shenzhen, December 2006 
on holism, and on the respect of complexity renders Confucianism capable of responding to the most concrete needs of humanity:

It can promote the respect of the environment without at the same time reducing production. It encourages the evolution of architecture and city planning that respects sustainable development. ${ }^{(33)}$

The small network formed out of interest in these ideas in 2006 includes people who have studied the natural sciences, economics, or law. However, those with specific philosophical training are generally held in suspicion, their specialisation deemed of little use. The mission is eminently practical: its goal is to provide the keys of ultimate understanding to professionals in positions of real social responsibility. The quasi-millenarian spirit nurturing this perspective does not rely on wisdom teachings inspired by philosophical texts but rather on a Confucianism transformed into a kind of super-science that can satisfy the needs of the future: "In basing itself on a Confucianism oriented towards things, in employing modern language and terminology, and in completely grounding itself in the cognitive structures of today, the Junde shuyuan academy intends to train a corps of generalists in company organisation and management who will usher in the interpenetration of Eastern and Western civilisations in order to restore the credibility of the timeless wisdom of ancient sages that can help establish a comprehensive peace for future generations." ${ }^{(34)}$

The legitimacy of such an undertaking is quite clearly derived from two sources: the Confucianism cultivated by M.W. seeks to root itself both in scientific rationality and in a sectarian fidelity towards a master "of advanced understanding" "who frequents influential circles" and "whose complex thought must continue to be studied and disseminated..." It is unlikely that such a vision of Confucianism, one that could be characterised as "scientological," is bound to enjoy a bright future. However, it does provide an interesting illustration of the fluidity of categorisations at work in the remnants of "Confucianism" today, a fluidity that informs "popular" movements (minjian) in a variety of different directions.

\section{From fluidity to the dissolution of modern categories: The utopian perspective}

To some extent, certain utopian dimensions of the "Confucian revival" can also be seen as a natural outcome, pro- jected into the realm of the imagination, of the ongoing questioning of categories and institutions. This is apparent in the work of Zhang Xianglong, a prominent university philosopher who has written a comparative study of Heidegger and Daoist thought. His advocacy of Confucian renewal has intriguingly evolved from a call for university reform to a utopian exploration that is no longer related to the academic world at all.

Zhang Xianglong started out as a participant in a circle of critical thinkers who traced the intrinsic limits of modern institutions such as university philosophy departments. Aware of the easily reductive nature of the neologism "philosophy" when attempting to define the essence of traditional Chinese thought, Zhang proposed an alternative concept of daoshuxue or "the teaching of the arts of the Way (Dao)," an umbrella term for the introduction of complementary disciplines based on the spirit of the "six arts" (liushu) of antiquity. The subsequent debate elicited by the proposal highlighted, at the same time, the legitimacy of such a questioning and the aporiae of the proposed solution, once the reflection in question strayed from a systematic assessment of the historical and anthropological characteristics of university education in itself. ${ }^{(35)}$

Zhang Xianglong's utopian project is to a certain extent the logical consequence of initial dissatisfaction with modern categories and institutions. If it is essential for Confucianism to resist being reduced to a university discipline, political ideology, or institutionalised religion, if the genius of Confucianism can only flourish within daily life, within an organic space that includes the ensemble of its arts and rituals inherited from the past, is it not tempting to imagine the possibility of re-establishing such a space within the modern world? It is only a small step to the project, stunning at first, to create, with hypothetical state support, a special "zone for the preservation of Confucian culture" (Rujia wenhua baohuqu), originally conceived according to the model of a "natural park" (ziran baohuqu), but also inspired by observation of the Amish community in the United States, which offers the possibility of a pre-industrial mode of life within modern society. This veritable "reservation" would gather a large

33. Ibid.

34. Forum cited.

35. See Zhang Xianglong, "'Zhexue' de huoguo yu fencun — Du Ruile 'Ruxue jingyan yu zhexue huayu' yiwen duhou gan" (Consequences and measures of "philosophy": Impression of a reading of the article by J. Thoraval), Zhongguo xueshu, 15, 2003, pp. 242-259; and Joël Thoraval's response, "Zongguo xiandai zhexue tizhi de 'yaoshu' zuoyong — huiying Zhang Xianglong de jige yijian" (The Role of 'pharmakon' in modern Chinese philosophy - A few remarks in response to Zhang Xianglong), Zhongguo xueshu, 16, 2004, pp. 255-266. 


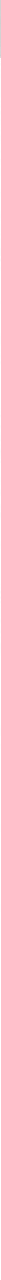

Confucius' birthday celebration, Queen Elizabeth stadium, Hong Kong, 2008. ๑) Sébastien Billioud

These concrete actions are manifestations of four goals: to establish Confucianism as a full-fledged religion, to establish Confucius's birthday as an official national holiday, to promote the comprehensive incorporation of Confucian principles into the nation's educational program, and finally, to create study halls dedicated to the master (Kongshen jiaotang) or Confucian Youth Associations (Kongjiao qingnian hul) in cities across the country in the hope that Confucianism can once again penetrate daily life. ${ }^{(4)}$

Two major preoccupations can be discerned in the words and writings of the Academy's leaders. Consistent with a perspective that can be traced back to Kang Youwei, their efforts at proselytism are deemed necessary to stem the worrying spread of Christianity, a menace before which the resistance of Buddhism and Daoism is considered insufficient. ${ }^{(4)}$ This anxiety is rooted in concern about the conservation of Confucianism as the cornerstone of national spirit. In fact, the publications of the Academy reveal a patriotism that, for all its different agenda, can easily be integrated with the official ideological discourse coming from the mainland. ${ }^{(45)}$

Not only would the requested bank holidays offer a chance to "meditate upon the meaning of our country's cultural heritage," the Confucian religion would also be likely to satisfy the need to "reinforce national cohesion and unity" (qianghua minzu de tuanjie yu ningjuli). Confucian teaching is the best possible contribution to the rise of the "spiritual civilisation" that the Communist authorities claim to be promoting to complement the "material civilisation," the political, economic, and technological order that the new capitalist development is making possible.

Despite growing material means and ambitions, the activities promoted in Hong Kong carry the mark of a certain religious and political pluralism: Confucianism is to be instituted as a religion comparable to the universal religions, although worthy of the special attention of the Chinese state. However, other movements dedicated to promoting Confucianism as a hegemonic religious institution are at work, not at the periphery but in the very heart of Chinese society. A

43. There are details on all these points on the Confucian Academy website. See http://www.confucianacademy.com/index_main.html, consulted on 1 November 2006.

44. Interview with Tong Yun-kai, Hong Kong, January 2008.

45. On this point, see the booklet distributed during the ceremony at Hong Kong Stadium in 2007 celebrating Confucius' birthday and the 10th anniversary of the handover, more specifically the speech by Tong Yun-kai. Kong li erwuwuba nian jikong dadian (Grand ceremony in honor of Confucius in year 2558 of the Confucian calendar), pp. 5-7. We can also mention that a vice-director of the bureau of religions of the PRC (zongjiaoju fujuzhang) attended the 2008 ceremonies that took place in September in Hong Kong in a smaller stadium that the previous year (around four thousand people attended the ceremony). 
2007 Confucius ceremonies in Hong Kong.

On the board it is written: "I love my China,

I sing the praises of the Motherland" o Sébastien Billioud

particularly radical example of this tendency will be the subject of the next section of this study.

\section{Towards hegemony: A "state religion"?}

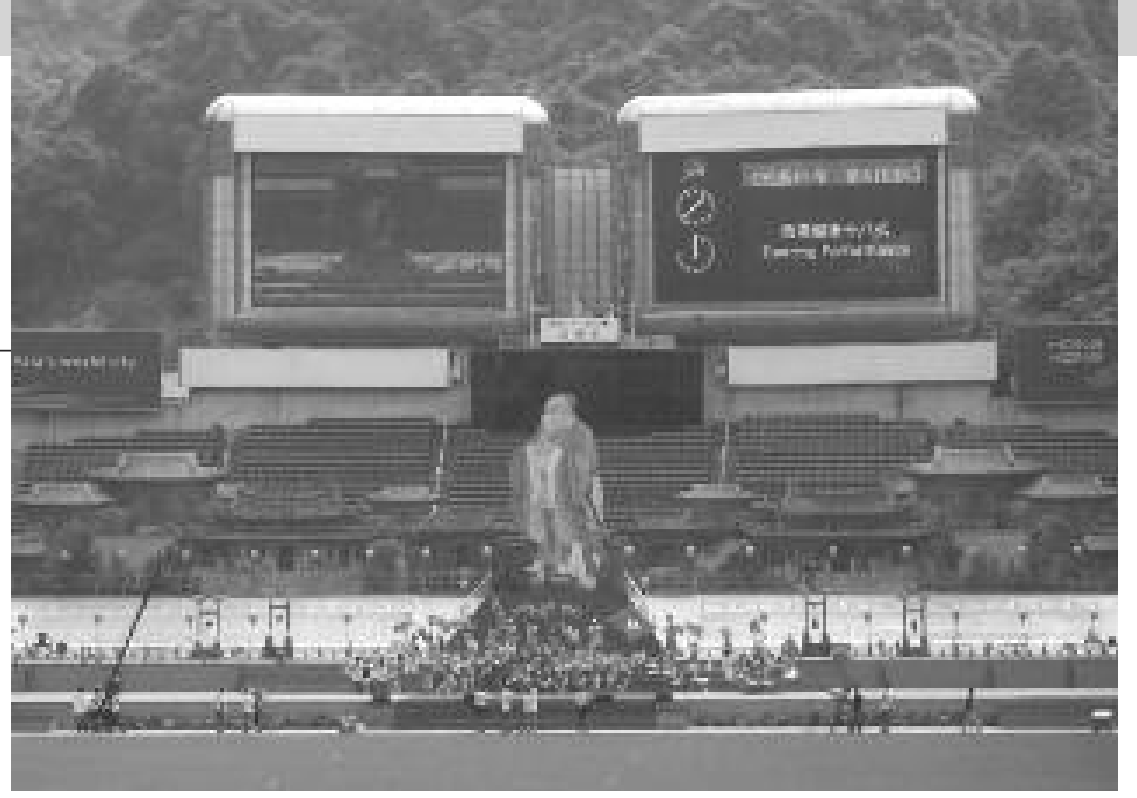

The prospect of Confucianism being promoted in the future as a national teaching or state religion (the Chinese expression guojiao allows for a certain degree of ambiguity) has become a shared belief among certain radical conservatives. While the idea of reviving "political Confucianism" emerged at the beginning of the 1990s with the intellectual Jiang Qing, who linked his position in an erudite fashion with the Gongyangxue school, ${ }^{(46)}$ the case of Kang Xiaoguang at the beginning of the century is particularly interesting, given the brutal frankness with which this sociology professor at the People's University and member of the brain trust of the former prime minister, Zhu Rongji, expresses himself:

Is it not a scandal that in China Confucianism does not have its own places of worship while any old Protestant group has a church? Is it normal that all the Temples of Culture are either deserted or only open to tourists? Shouldn't the state be more concerned about what constitutes the fundamental teaching of the Chinese nation? ${ }^{(4)}$

It is fairly obvious, however, that he is less concerned about the vitality of a spiritual or religious orientation than with searching for the most effective means to promote, with the support of the government, "cultural nationalism," which he feels is necessary in the face of contemporary globalisation. In a book entitled Governing Humanely (Renzheng): The Third Way of Chinese Political Development, in which Kang opposes both Marxist orthodoxy and Western liberalism, he emphasises the following points: The teaching that needs to be promoted is indissolubly religious and political. The socio-cultural order that should be instituted shares a certain similitude with a "quasi-religious system" in that it promotes a return to the ancient ideal in which there is no separation of the exercise of power from ethical teachings. While such an argument, informed by the ambiguity that characterises the traditional notion of jiao (teaching), can easily be championed for tactical ends, Kang also clearly insists upon the necessity of developing the strictly religious potential of Confucianism:

Confucian teaching (rujiao) needs to permeate daily life; it must become the religion of the entire nation. In the end, it is only by becoming the religion of the people as a whole that it can become operative in daily life. ${ }^{(4)}$

The state plays a crucial role in such an undertaking: it must "support the teaching of Confucianism (rujiao) and grant it the status of national teaching (guojiao)." (49)

Despite its sometimes archaic vocabulary, Kang's conception is clearly opposed to the imperial past: what unifies the diffusion of teaching (jiao) with political practice is no longer the rituals of yore but a modern ideology (not without its own ceremonial aspect) inspired by an instrumental rationality. Its difference from certain "popular" movements (minjian), which harbour real suspicions toward any "official" initiative, is also evident. For Kang, "Confucianisation" is a top-down affair, its capacity to be a future "national religion" being tied to confidence in the totalising action of state power to shape the political, educational, and culture spheres.

Other works by Kang Xiaoguang leave no room for ambiguity as far as the political orientation of this "quasi-religious" project is concerned. In a text entitled "The Principles of Cultural Nationalism," he asserts that "the goal of transforming Confucian teaching into national teaching" (rujiao wei guojiao) is to foster the cultural renaissance of China and further its rise as a great world power. Referring to Kang Youwei, he insists on the fact that "Confucianism was never a mere school of thought: it fulfilled an educational/transformational function (jiaohua) as the religion of all the people (quanmin zongjiao) thanks to the support of the state (guo-

46. Cf. Ji Zhe, "Confucius, les libéraux et le parti," La vie des idées, no. 2, May 2005, pp. 9-20

47. Interview, Beijing, June 2006.

48. Kang Xiaoguang, Renzheng, Zhongguo zhenzhi fazhan de di san jiao daolu (A policy based on the sense of humanity: The third way of Chinese political development), Singapore, Global Publishing, 2005, p. 191.

49. Ibid., p. 190. 
jia zhichı)." Explicitly presented as an ideological ensemble, cultural nationalism must accomplish three tasks: promote cultural heritage (zhengli guogu), mobilise society (shehui dongyuan), and recreate a system or a new set of institutions (zhiduhua). A new, specially-trained elite would naturally take on the role of mediators between the state, as initiator, and the various popular movements that would need to be controlled. ${ }^{(50)}$ Such a radical position has elicited reactions in intellectual circles, and while certain ideologues are somewhat sympathetic, the official discourse maintains a prudent distance from such maximalism, which could turn into a source of instability. ${ }^{(51)}$

\section{A future "civil religion"?}

Of interest in the current debate is a position that represents a kind of compromise between simple religious pluralism and the temptations of religious hegemony. Since the beginning of the century, debate over the possibility of a Chinese "civil religion" illustrates not only the influence of diverse Western "theologico-political" experiences, both European and American, but also the difficulties or perhaps the aporiae of a future religious institutionalisation of Confucianism within a liberal or democratic public space.

Chen Ming, the founder of the review Yuandao, became instantly famous in the second half of the 1990s for his defence of a "contemporary mainland Confucianism" (dalu de xin rujia) that defined itself in opposition to the metaphysical tenor of the generation of refugee philosophers in Hong Kong and Taiwan. Close to the philosopher Li Zehou both are actually natives of Hunan province - and interested, like $\mathrm{Li}$, in a pragmatist interpretation of Chinese culture, Chen rejected the construct of "philosophical systems" in favour of a practical, social, and popular vocation for modern Confucianism. ${ }^{(52)}$ However, the question of a possible religious status for Confucianism within post-communist society has gradually become pivotal for him, inspired by the American model of "a civil religion."

Thus for Chen Ming, "civil religion (gongmin zongjiao) is not merely one of the possible brands of Confucian renaissance: it is the way by which this renaissance can be accomplished." The reference is borrowed from a well-known study by the American sociologist Robert Bellah of civil religion in the United States. Bellah begins by citing the numerous references to God in the speeches of American presidents and public discourse in the United States, despite the official secularism spelled out in the First Amendment of the U.S. Constitution: ...the separation of church and state has not denied the political realm a religious dimension. Although matters of personal religious belief, worship, and association are considered to be strictly private affairs, there are, at the same time, certain common elements of religious orientation that the great majority of Americans share. These have played a crucial role in the development of American institutions and still provide a religious dimension for the whole fabric of American life, including the political sphere. This public religious dimension is expressed in a set of beliefs, symbols, and rituals that I am calling American civil religion. ${ }^{(53)}$

If the idea of a civil religion attracts Chen Ming, it is because it seems consistent with his own essentially popular and pragmatic orientation as opposed to more abstract and dogmatic ones:

$$
\begin{aligned}
& \text { Mou Zongsan's Confucianism as the 'perfect teaching' } \\
& \text { seems too informed by emotion, Jiang Qing's notion } \\
& \text { that China should be a Confucian state that unifies the } \\
& \text { political and religious (zhengjiao heyi de rujiao guojia) } \\
& \text { is surely too simplistic, and Kang Xiaoguang's program } \\
& \text { to transform Confucianism into a state religion (rujiao } \\
& \text { guojiaohua) is hardly applicable. However, civil reli- } \\
& \text { gion is fundamentally oriented toward the foundation } \\
& \text { of society: it is compatible with freedom, democracy, } \\
& \text { and the constitution, and it can contribute to their } \\
& \text { proper functioning. }{ }^{(54)}
\end{aligned}
$$

More precisely, for Chen, this new concept constitutes the long-sought solution to two recurrent difficulties, one theoretical and the other practical. The theoretical difficulty, which is well known, arises because of the unsuitability of the Western notion of religion:

While it is certainly true that calling Confucianism a religion engenders considerable theoretical problems,

50. Kang Xiaoguang, Dangdai Zhongguo dalu wenhua minzuzhi yundon yanjiu, 2008, Global Publishing Singapore, pp. 234-238. On Kang Xiaoguang's idea of an "alliance of the elites" (jingying lianmeng), see Sébastien Billioud, "On the Art of Dissipating Clouds: Reflections Based on the Political Theory of Thomas Metzger," Etudes Chinoises, vol. XXVI, 2007, pp. 210-216.

51. Sébastien Billioud, "Confucianism, Cultural Tradition, and Official Discourse in China at the Start of a New Century," China Perspectives, 2007/3, pp. 53-68

52. Chen Ming, "Bianhou" (Postface), Yuandao, 5, 1999, pp. 465-466. On this context, Joël Thoraval, "La tentation pragmatiste dans la Chine contemporain," in Anne Cheng (ed), La pensée en Chine aujourd'hui, Paris, Gallimard, Folio, 2007, pp. 103-134.

53. Robert Bellah, "Civil Religion in America," in Beyond Belief, Essays on Religion in a Post-Traditionalist World, Berkeley, University of California Press, 1970, pp. 168-189 and especially p. 171.

54. Chen Ming, "Rujia gongmin zongjia shuo" (On Confucianism as civil religion), website of the "Pinghe shuyuan" Academy: http://www.poinghesy.com/data/2007/1016/article_1594 
seeing it as a civil religion involves fewer difficulties. As long as the concept of civil religion is not too rigidly based on the American example or on the modern context of the notion of 'civil' (gongmin) but, instead, is understood in the larger sense as designating communality (gonggongxing), then it is no exaggeration to say that China is the country where civil religion was most a reality. ${ }^{(55)}$

Confucian lore is filed with the equivalents of the heroes, sites, and necessary sacred rituals that Bellah writes of in the context of American history. A modern civil religion would make it possible to formalise and rationalise these symbols within the "life of the state" (guojia shenghuo).

The issue of institutionalisation is the crux of the practical difficulty: Confucianism possesses "structural characteristics that on the one hand meld with popular beliefs, and that on the other hand inherently blend with political power." ${ }^{(56)}$ The fact that Confucianism has been confined to the people (minjian) since the abolition of the Empire is certainly a point of weakness, but the future civil religion could thus nourish itself through those elements that have remained vibrant rather than on ideological discourse removed from the people. ${ }^{(57)}$ Thus this new concept comes to function as a force of mediation between the vitality of popular Confucianism and a hoped-for modern political regime. ${ }^{(58)}$

There is no doubt that the debate over the future of Confucianism as civil religion confronts two major obstacles. The first is naturally the application to the Chinese context of conceptions that are profoundly conditioned by American historical experience and that represent only one of the possible interactions of the political and the religious. ${ }^{(59)}$ Robert Bellah was the first to put an accent on the necessary critical dimension to the notion of "civil religion" in the United States, without which it can easily degenerate into a kind of "national self-idolatry" tantamount to "American Shintoism." ${ }^{\left({ }^{00}\right)}$ The second problem arises from the vague way in which this term is now often used and applied without distinction to pre-modern situations. From this perspective, it is probably regrettable that Robert Bellah himself recently proposed using the term "civil religion" to characterise the Confucianism the Qing Dynasty Manchu elite propagated as a means of assuring the political unity of the Empire. ${ }^{(6)} \mathrm{Chi}$ nese advocates of a national religion have not failed to make use of Bellah's strange anachronism. Such loose application of the term can only encourage the sentiment of a fictional continuity with the imperial past and complicate the debate over the indivisible historical link between the idea of civil religion and the modern idea of a society of citizens: indeed, doesn't conflating civil religion with traditional state religion obscure the fact that the concept only makes sense within a modern democratic context where political legitimacy is no longer derived from Heaven but from the people?

Beyond the concrete policies that they are likely to foster, the three perspectives under debate (Confucianism as a specific, state, or civil religion) are especially interesting in the way that they highlight the difficulties faced by the various attempts to institutionalise Confucianism. The difficulties are further complicated by the fact that they are as much the product of the particularity of Chinese cultural tradition as of the uncertainty facing China's future as a political community in its relations with the democratic model that is Western it in its origin.

\section{Conclusion}

What conclusions can be reached after this brief examination of religious developments within the current "Confucian revival"?

The importance of these developments considering either the multiple parallel developments discernible within Chinese society today (whether in terms of the various flourishing forms of Buddhism, the unexpected effects of Christian proselytism, or the emergence of new sectarian movements claiming tradition as inspiration) or the diverse opposition they have inevitably engendered should not, of course, be exaggerated. Ultimately, appreciating the future vitality of this phenomenon requires taking into account two essential tensions. First of all, there is a sort of intermediate space, which remains ill-defined, between the force of spiritual quests that sometimes translate more into a greater desire for religion than actual religiosity and the reality of individual and communal

55. Ibid.

56. Ibid.

57. Ibid.

58. The idea of a Chinese civil religion based on Confucianism is also defended by certain Christian intellectuals. Thus for the sociologist of religion Yang Fenggang, such a program would guarantee both religious pluralism, as in the United States, and the necessary promotion of Chinese culture. But it is difficult not to notice how, despite his liberalism, this Protestant thinker's encouragement of a civil religion that breaks with the post-communist state's official atheism favors a surreptitious Christianisation of Confucian doctrine, emphasising in particular "the accent on the transcendent dimension of Heaven (tian) endowed with will..." Yang Fenggang, "Duiyu rujiao zhi wei jiao de shehuixue sikao" (Soiological reflections on Confucianism as religion), 2005, website of the review Yuandao: $/$ dispbbs.asp?boardID=2\&ID=26896\&page $=15$.

59. Cf. for example Marcel Gauchet's remarks based on Bellah in La religion dans la démocratie. Paris, Gallimard, Folio, 1998, p. 69

60. Robert Bellah, op. cit., p. 168, note.

61. Robert Bellah, "Gongmin zongjiao yu shehui chongtu" (Civil religion and social conflicts), Ershiyi shiji (Twenty-first century), Hong Kong, 2003, electronic edition: : http://www.cuhk.edu.hk/ics/21c/ supplem/essay/9501079g.htm. 
practices that are still dispersed and seeking social and institutional space. The creativity of the popular movements active today unfolds within this interval between the real and the imaginary, expressing itself in forms that are by definition difficult to anticipate. But there is another unresolved tension between an aspiration towards official institutionalised status and an attachment to the autonomy of Confucian teaching, the value of which is to be found most prominently within popular manifestations. The role of the state relative to a new Confucianism remains very complicated due to the twists and turns of the last century's political history.
It is for these reasons that an appreciation of the potential for religious revival requires considering a form of mediation that traditionally established a link between individual sentiments and collective behaviour as much as between the world of political authority and ordinary practices: what we have in mind, of course, are rites $\left(l_{i}\right)$ that have always been essential to the diverse expressions of "Confucianism." Is a modern Confucian-inspired neo-ritualism possible? Our next study will pursue this question.

\section{- Translated by Christopher Storey}

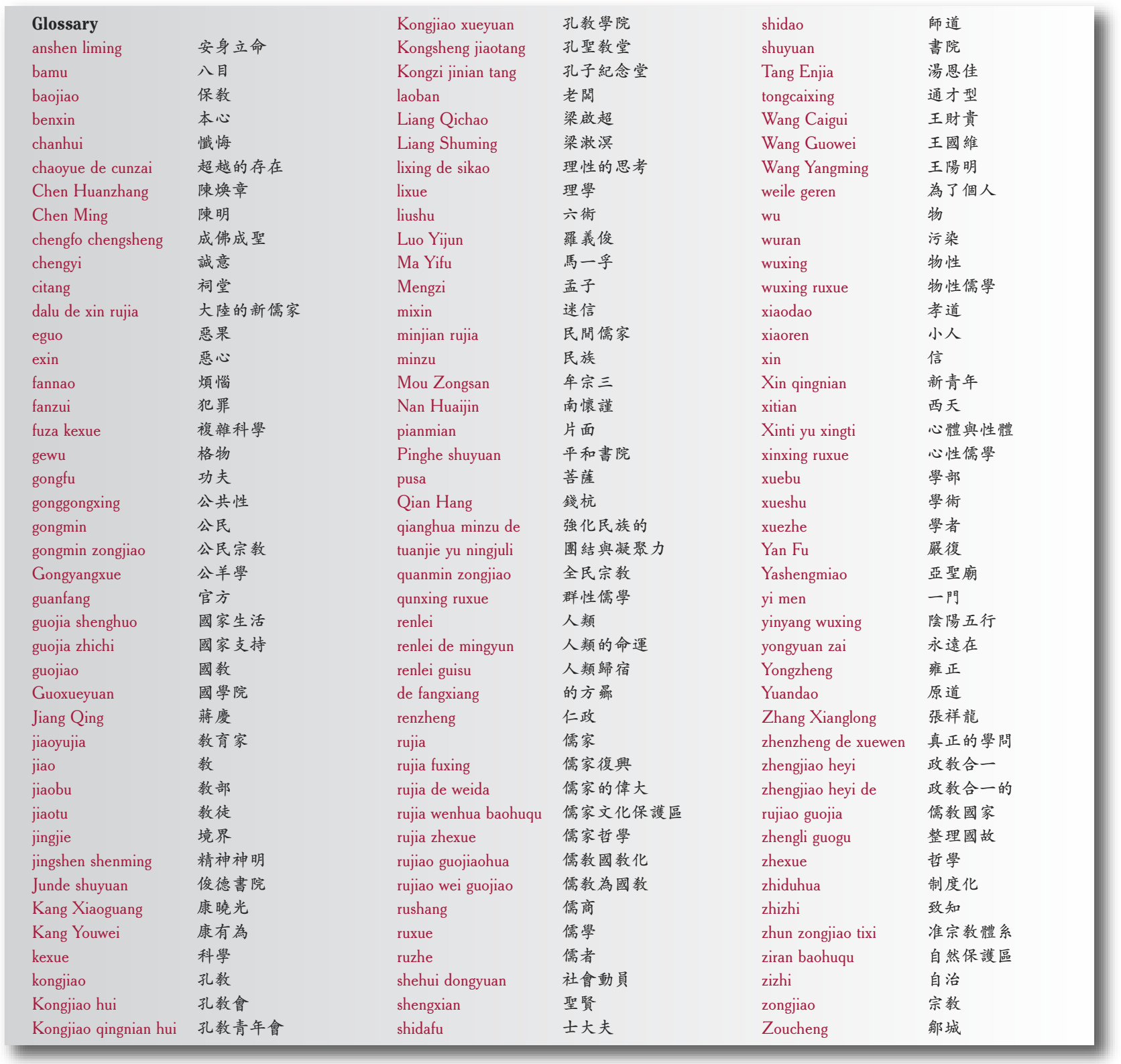

